\title{
On Printing and Decision-Making: The Management of Information by the City Powers of Lyon (ca. 1550-ca. 1580)
}

\author{
Gautier Mingous
}

In the year 1562, as religious division became acute in the city of Lyon and the consulat tried its best to re-establish a semblance of order, the municipal government forbade artisans from meeting in assemblies. This measure was an attempt to restore calm and avoid a potential confrontation. To implement the ruling, the city council did not follow its standard procedure to communicate such a decision: no town crier was requested to spread the information. Instead of the town crier, the municipal government employed two sergeants of the municipality to affix more than 140 posters for display at the different crossroads of the city. The man who 'carries the glue' was even given a small purse of deniers to perform the deed. ${ }^{1}$ This decision is one of the rare documented instances of the very concrete and material use of printing by the city council in the middle of the sixteenth century. ${ }^{2}$

The city of Lyon makes an excellent case study to analyse the growing importance of print as an official information medium in times of political, religious and health crises. The relationship between print and decision-making has mostly been studied within the framework of royal rule, with a distinct focus on the seventeenth century. ${ }^{3}$ The relation between print and power in French

1 Archives municipales de Lyon (hereafter AML), CC 1099 : "comprins le sallaire d'un homme qui portoit la colle".

2 Eugène Vial, Institutions et coutumes lyonnaises (Lyon: L. Brun, 1903), p. 27.

3 Jean-Pierre Seguin, Linformation en France, de Louis XII à Henri II (Geneva: Droz, 1961); Jean-Pierre Seguin, L'information en France avant le périodique. 517 canards imprimés entre 1529 et 1631 (Paris: G.P. Maisonneuve et Larose, 1964); Xavier Prévost, Les premières lois imprimées. Étude des actes royaux imprimés de Charles VIII à Henri II (1483-1559) (Paris: Édition de l'École nationale des Chartes, 2018). For examples of royal use of print see Hubert Carrier, La Presse de la Fronde (1648-1653): les Mazarinades. La conquête de l'opinion (2 vols., Geneva: Droz, 1989); Robert Chartier, Les usages de l'imprimé (XV $-X I X^{e}$ siècles) (Paris: Fayard, 1986); Hélène Duccini, Faire voir, faire croire. L'opinion publique sous Louis XIII (Seyssel: Champ Vallon, 2003); Gilles Feyel, L'annonce de la nouvelle. La presse d'information en France sous l'Ancien Régime (1630-1788) (Oxford: Voltaire foundation, 2000); Héloïse Hermant, Guerres 
cities in the sixteenth century has been discussed indirectly. ${ }^{4}$ This article investigates the slow introduction of print in sixteenth-century Lyon and the use of this new information medium by the city council and governors.

For most of the sixteenth century, the relationship between printing and the urban powers of Lyon had been something of a case of missed opportunity. The municipal powers used print only infrequently during the first decades of the sixteenth century. It was the economic capital of the kingdom, and the city had grown into a capital of printing in Western Europe at the end of the fifteenth century. ${ }^{5}$ The exceptional dynamism of Lyon's commerce and of its book market even played a role in the diffusion of the Reformation, precipitating the very crisis the city government would later combat. ${ }^{6}$ Despite the strength of the book industry on its doorstep, the consulat seldom resorted to this medium to handle its affairs, favouring instead the traditional use of town criers to spread information orally. ${ }^{7}$

The authorities would later review their use of print and would turn to it as a tool of governance only after the religious divide of the 155 os and the conflicts that broke out during the following decade. As a border city situated at the junction of several trade routes, the city was not exempt from the growth of Calvinism and the dissolution of religious unity during the French Wars of Religion. This situation led to growing conflicts, culminating in the Protestant occupation of Lyon, with the Huguenots laying siege to the city in 1562. Following the Catholic reconquest of the city in 1563 , Lyon was turned into a bastion of Catholicism.

In the context of religious division, civil wars and health crises, the necessity to inform the citizenry properly and thoroughly became a priority for the

de plumes. Publicité et cultures politiques dans l'Espagne du XVII e siècle (Madrid: Casa de Velasquez, 2012).

4 For example, Marie-Thérèse Blanc-Rouquette, La presse et l'information à Toulouse des origines à 1789 (Toulouse: Association des publications de la faculté des lettres et sciences humaines de Toulouse, 1967); Louis Desgraves, La presse à Bordeaux (XVI ${ }^{e}-X V I I I^{e}$ siècles) (Bordeaux: Sud Ouest Université, 1996); Delphine Estier, '1589-1594: la maîtrise de l'opinion à Lyon pendant la Ligue, ou le secret nécessaire', Rives nord-méditerranéennes, 17 (2004), pp. 63-83; Denis Pallier, Recherches sur l'imprimerie à Paris pendant la Ligue (1585-1594) (Geneva: Droz, 1976); Anne Béroujon, Les écrits à Lyon au XVII e siècle. Espaces, échanges, identités (Grenoble: Presses Universitaires de Grenoble, 2009).

5 Richard Gascon, Grand commerce et vie urbaine au XVIe siècle. Lyon et ses marchands (environs de 1520-environs de 1580) (2 vols., Paris/The Hague: Mouton, 1971).

6 See Yves Krumenacker (ed.), Lyon 1562. Capitale protestante. Une histoire religieuse de Lyon à la Renaissance (Lyon: Olivétan, 2009).

7 Didier Lett and Nicolas Hoffenstadt (eds.), Haro! Noël! Oyé! Pratiques du cri au Moyen Âge (Paris: Presses universitaires de la Sorbonne, 2003); Jean-Pierre Vittu, 'Instruments of Political Information in France', in Brendan Dooley and Sabrina Baron (eds.), The Politics of Information in Early Modern Europe (London: Routledge, 2011), p. 162. 
municipality. The local representative of the king and the governor also started to consider print as a valuable medium of communication. They used print to spread news, orders and information about local policies. During the second half of the sixteenth century, the urban powers made many attempts to commission print. These endeavours aimed to institutionalize the use of print to make it a communication medium of official and authoritative information that would be fully legitimate in the eyes of the population.

This transformation went hand in hand with new ways of organising the production of print with the purpose of standardising its content and its circulation. The ultimate goal was for print to become a real tool of urban government whose efficiency would no longer be questioned. However, the situation was very different from the seventeenth century onwards, when print would really become a full-fledged informative medium. In Lyon during the civil wars, the government's relationship to print was still hesitant and mostly experimental. However, the growing number of printed orders shows that urban elites attached more and more importance to this medium when it came to decision-making.

This paper examines the urban powers' new relationship to print, as well as print's significance compared to other communication tools. It will explore the transformation of print into a trustworthy information medium, especially at a time when authorities still favoured orality for its solemnity and efficiency. The basis of much of this research comes from the municipal registers and, more importantly, to the pamphlets conserved in the municipal library of Lyon. In order to shed light on these questions, I will first analyse the traditional use of print by urban powers, with particular attention to its strong ties with orality. This will lead to a focus on the city council and on the governor's efforts to turn print into an official and far-reaching communication medium to deliver information. This paper will finally examine print during two specific moments of crisis: the first civil wars in Lyon and the 158 os health crisis due to the plague. These cases illustrate the diversification of the use of print as the city faced complex challenges.

\section{Printing and Distributing Information: The Traditional Use of Print in Lyon}

The consulat was the urban institution in charge of handling the daily affairs of the city. It was composed of twelve échevins who served two-year terms and were elected yearly in groups of six. They oversaw all matters relating to commerce, urban policing and supply of provisions. The échevins met at very regular intervals, usually on a weekly basis, and held an assembly that included 
a secretary whose role was to describe in detail the content of all deliberations in municipal registers. ${ }^{8}$ Together with the municipal accounting records, which list consulat expenditures, these documents are key sources of information on the nature and frequency of the use of printing by the consulat. When the échevins resorted to print, they ordered copies of acts or privileges granted by the Crown to the city as well as posters, which usually served commercial purposes.

Town criers were appointed by the municipality and delivered information through official announcements. ${ }^{9}$ These included what Michèle Fogel has called 'information ceremonies'.10 Announcements from criers were meant to be as formal as possible, relying on musical instruments and specific set phrases, all of which added a high degree of solemnity to the message delivered. While such a performance mostly relied on oration and music, print was involved to some degree as well. This hybrid practice, where orality and print coexisted, was paramount for the authorities' process of communicating with the rest of the urban community. ${ }^{11}$ Many printed documents containing the proclaimed texts stated that the information had been 'cried and published'. ${ }^{12}$ The term 'publish' might mean that the information was put up on the city's walls as broadsheet posters, but it could also refer to the public crying itself, 'published' meaning made public, in this case..$^{13}$

There is little evidence to provide an estimate of the number of public cries that were printed. Some official documents, like price tables of bread, were most certainly turned into a written publication, as printed copies have been conserved. Similarly, an order of the seneschal to the city dating from 31 January 1568, was cried and printed. Indeed, the document mentions that a copy of the text was "attached" in different places of the city, such as the gates of

8 Claude de Rubys, Histoire véritable de la ville de Lyon (Lyon: Bonaventure Nugo, 1604), USTC 6900422, pp. 473-476.

9 Xavier Nadrigny, Information et opinion publique à Toulouse à la fin du Moyen-Âge (Paris: Éditions de l'École des Chartes, 2013), pp. 239-267; Vittu, 'Instruments of Political Information', p. 162.

10 Michèle Fogel, Les cérémonies de l'information dans la France du XVIe au XVIII e siècle (Paris: Fayard, 1989).

11 Thierry Dutour, 'Lélaboration, la publication et la diffusion de l'information à la fin du Moyen Âge (Bourgogne ducale et France royale)', in Lett and Hoffenstadt (eds.), Haro ! Noël! Oyé, p. 153.

$12 \quad \mathrm{AML}, 6$ FI 651.

13 Jean Masset, Jean Nicot and Aymar de Ranconnet, Thrésor de la langue françoyse (Paris: D. Douceur, 1606), USTC 6o16155, p. 524; See 'Publier' in Antoine Furetière, Dictionnaire universel, contenant généralement tous les mots françois tant vieux que modernes, et les termes de toutes les sciences et des arts (3 vols., The Hague: A. et R. Leers, 169o), III, p. 261. 
the city hall, on the walls of churches and other locations. ${ }^{14}$ This clearly proves that print and public crying were used simultaneously. The printed broadsheets reproducing messages from town criers were used to transmit information supposed to be known by all. However, the surviving information about them is too scarce to determine their exact numbers, forms and frequency. The municipal accounting records do not specify any payment for printed copies of public cries and the broadsheets themselves have not been conserved.

In the first half of the sixteenth century, official print was mainly used to communicate information about the price of bread and about the city's fairs. The provision of food to the Lyonnais inhabitants was one of the many responsibilities of the consulat. Indeed, in periods of scarcity, they regulated bread prices to prevent people from being overcharged. One of the few preserved broadsheets in the Archives Municipales of Lyon is a price table for bread for August 1556. This specific broadsheet illustrates the purpose of this kind of document: delivering information visually and to the greatest number of people..$^{15}$

The fairs were the main commercial events in the city, which gathered merchants coming from all over Europe in January, around Easter, in August, and in autumn. ${ }^{16}$ The échevins were in charge of controlling the fair activities in the city and were required to communicate the decisions made by the king and the privileges granted to the merchants. During the fairs, the échevins commissioned hundreds and even thousands of printed documents in order to inform merchants about the privileges of the city. ${ }^{17}$ For example, in January 1560 , the printer Pierre Fradin received up to 6o livres tournois for printing 536 copies of fair privileges, which were meant to be distributed to the merchants attending the king's fair. ${ }^{18}$

During the 156os and the 1570s, print orders from the city council increased, and more importantly, diversified. Other official documents were added to the existing body of printed fair privileges and price tables, such as broadsheets

14 Ordonnance de messieurs les Seneschal et gens tenans le siege presidial en la ville de Lyon, contre les detenteurs des biens de ceux de la religion reformée : ensemble les noms et surnoms des seditieux et rebelles contre la majesté du Roy nostre Sire (Lyon: Michel Jove, 1568), USTC 5333 .

15 Jacqueline Boucher, Vivre à Lyon au XVIe siècle (Lyon: Éditions Lyonnaises d'Art et d'Histoire, 2001), p. 47; Jamie Cumby, 'Bread and Fairs: Broadsheet Printing for the Municipality of Lyon, 1497-1570', in Andrew Pettegree (ed.), Broadsheets. Single-Sheet Publishing in the First Age of Print (Boston/Leiden: Brill, 2017), pp. 170-171.

16 Marc Brésard, Les foires de Lyon aux XV et XVI e siècle (Paris: Picard, 1914), pp. 66-69; Boucher, Vivre à Lyon, pp. 46-48; Rubys, Histoire véritable, pp. 340-343.

17 For example, Michel Jove is requested to print 3,500 receipts during the fair of All Saints Day in 1575. AML, CC 1233 .

18 AML, CC 1089. 
concerning the taxes received by the municipality. The documents that deal with the exit fees of merchandise, the rêve et foraine cartulaire, also appeared in print. These acts allowed the municipality to be informed about the proper observance of commercial rules for merchants in the city. Therefore, this use of print makes it clear that city authorities gradually optimised the management of information related to commerce, and devoted an essential part of their yearly budget to the control of the city's activities. ${ }^{19}$

In the sixteenth century, the municipality of Lyon increasingly started to rely on print to deliver information to its citizens. Pamphlets, posters or broadsheets became an increasingly familiar sight to the Lyonnais inhabitants by the middle of the sixteenth century. ${ }^{20}$ These documents were often displayed in the open air, which means that they could be subject to the deteriorating effects of bad weather and simply became illegible to the inhabitants of the city. Likewise, the authorities were also prompted to remove broadsheets whenever the information they displayed was no longer relevant, to make way for updated posters. ${ }^{21}$ Print, no matter how official it might have been, had a short lifespan and could be difficult to conserve. In the sixteenth century, the authorities did not yet conserve these printed documents consistently, as only six posters are currently to be found in the Archives Municipales of Lyon. ${ }^{22}$ Nevertheless, the absence of print in the city's memory does not mean that urban powers disregarded this communication medium. Official print was used to deliver information efficiently that needed to be communicated to the largest possible number of people.

\section{Legitimizing Information: Print and Tokens of Power}

The consulat relied on several printers to print these documents. The minutes of the municipal registers list the orders meticulously, whereas the names of printers hired by the municipality during the 155 os are not always noted. ${ }^{23}$ When specific references to printers appear, they are only to be found in accounting records rather than in municipal deliberations. ${ }^{24}$ Their absence

\footnotetext{
19 Cumby, 'Bread and fairs', p. 186.

20 Cumby, 'Bread and fairs', pp. 163-164.

21 Béroujon, Les écrits à Lyon, pp. 113-114.

22 Cumby, 'Bread and fairs', p. 171.

23 AML, BB 74.

24 A clear distinction should be made between orders for printing work and the supplies purchased from stationers and printers. These printers were only requested to provide the consulat with ink and paper, not to print documents per se.
} 


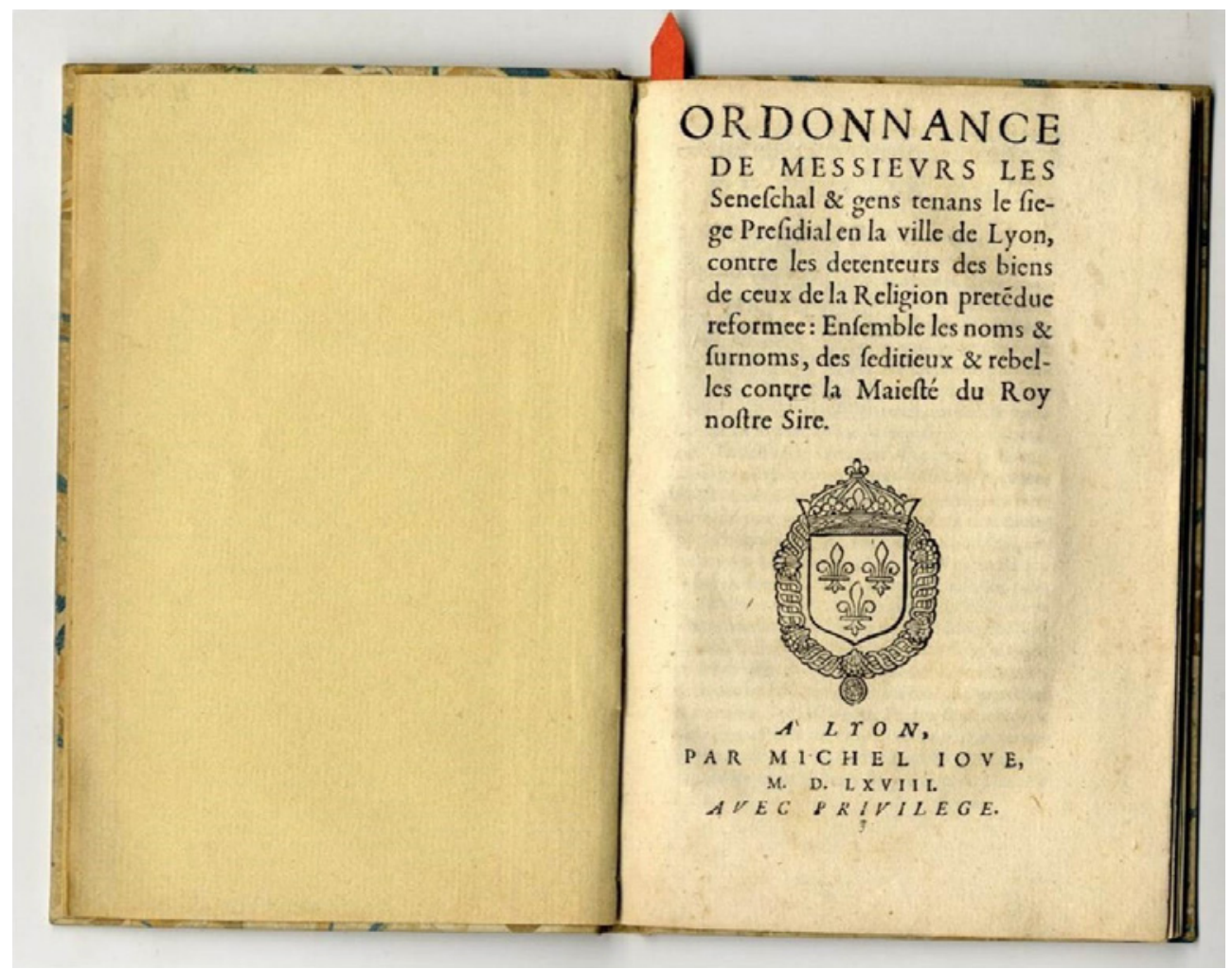

FIGURE 2.1 Ordonnance de Messieurs les Seneschal \& gens tenans le siege Presidial en la ville de Lyon (1568), title page

MUSÉE DE L'IMPRIMERIE ET DE LA COMMUNICATION GRAPHIQUE DE LYON. ALL RIGHTS RESERVED

from the official municipal registers, which constitute the written memory of the city, suggests that printers still played a lesser role in the 1550s, and that printers were not explicitly involved in the exercise of power. Lack of record keeping about print commissions by Lyon's authorities reveals that, in the sixteenth century, print was not considered important enough to be part of the official memory of the city. However, the 156 os and the 157 os were a turning point for printers working for the municipality. The échevins not only started to name them consistently in the registers, but also drew on a smaller number of printers to print these official orders than previous decades. Indeed, during this period, only two printers rose to prominence and became the official personnel behind the publications of the échevins.

Benoit Rigaud was the first printer to work in the service of the governor of Lyon. He was a bookseller and a printer who managed a very successful 
business from 1555 to the late 159 os. ${ }^{25}$ First, he first published pamphlets about law, medicine or political news. He gradually specialised in reprinting small, inexpensive pamphlets, editions of edicts, orders and royal letters, which were popular throughout the kingdom. Between June and December 1563, Rigaud issued no fewer than 44 pamphlets. ${ }^{26}$ Most of these pamphlets were orders signed by the seneschal or the governor 'with the permission of' or 'on command of' the representative or the lieutenant of the king, intended for local circulation. Rigaud became the de facto printer for all the governors of Lyon in the 156 os. He received this official status from privilege letters dating from 1 August 1566, granting him a three year monopoly on the printing and sale of the orders promulgated by the king. ${ }^{27}$ By relying on an appointed printer, the city governor gradually gained control over the circulation of the king's word, bypassing the usual communication channels of the Crown.

A similar process can be observed with the second printer working for the échevins of Lyon during this same period, Michel Jove. His first works as a printer dated back to $155^{1}$ and he eventually started printing edicts and royal orders in the service of the urban powers in $1568 .{ }^{28}$ In February 1569, Jove received permission letters from the king that granted him a monopoly on printing orders and royal edicts in Lyon, a decision that was officially confirmed in $1574 .{ }^{29}$ His appointment might have been motivated by his record of printing in favour of the Catholic faith, in order to rebuke Protestant "heresies." 30 The official status granted to him by the king explains the political orientation of his printing work. Indeed, between 1557 and 1576, almost half of the editions that Jove produced were political documents, such as edicts, orders and letters patent sent by the king to the seneschal or the governor.

25 Henri Baudrier, Bibliographie lyonnaise. Recherches sur les imprimeurs, libraires, relieurs et fondeurs de lettres de Lyon au XVI ${ }^{e}$ siècle (12 vols., Paris: F. de Nobele, 1964), III, pp. 175-176.

26 Baudier, Bibliographie lyonnaise, III, pp. 214-226.

27 Archives Départementales du Rhône (hereafter ADR), BP 3642.

28 Baudrier, Bibliographie lyonnaise, II, p. 82.

29 ADP, BP 3643; Baudrier, Bibliographie lyonnaise, II, p. 84.

30 ADR, BP 3643. Jove was the printer of Gabriel de Saconnay, a vehement advocate of the Catholic faith. His work Discours des premiers troubles advenus à Lyon, published in 1569 (USTC 6353), is one of the most widespread books which helped the Catholic reconquest of the city. Jérôme Sirdey, Réforme/Contre-Réforme. La production comparée de deux libraires lyonnais de la seconde moitié du XVI e siècle: Michel Jouve et Jean Saugrain (Lyon: Mémoire d'étude de l'Ecole Nationale supérieure des Sciences de l'information et des bibliothèques, 2010). 
TABLE 2.1 Documents printed by Michel Jove between 1557 and 1576

\begin{tabular}{lcc}
\hline Subject & Number & Percentage \\
\hline Royal Edicts and Orders & 75 & $\mathbf{3 9 \%}$ \\
Parliamentary decisions and & 46 & $23,8 \%$ \\
political letters & & \\
Religion & 40 & $20,7 \%$ \\
Tributes & 13 & $6,7 \%$ \\
Other & 19 & $9,9 \%$ \\
Total & 193 & $100 \%$ \\
\hline
\end{tabular}

Most of these printed documents were published as early as 1566 , reaching a peak in 1568 with 26 acts of the king and his administration. ${ }^{31}$ This period of intense activity in the service of the Crown led to a growing number of commissions given by the consulat of Lyon. From the beginning of the 1570 os to the end of his career, Michel Jove became the official printer of the municipality and was trusted with most of the print orders emanating from the échevins. ${ }^{32}$ This growing number of commissions concerned official documents dealing with commerce or local policies. The échevins' decision to employ Michel Jove as their official printer had nothing to do with chance. Indeed, selecting a royally appointed printer to print municipal documents was a deliberate choice by the consulat. This decision increased the authoritativeness of the municipality's print, as it was linked not only to the coats of arms of the city but also to the legitimacy of a printer associated to the name of the king.

To be seen as authoritative objects, printed documents had to demonstrate their connections to power. The first of these tokens of power is clearly visible: the coat of arms or the name of the authorities sending the message. Use of these traditional symbols aimed to disclose the sender's identity at first glance. Even if most pamphlets usually came from the municipality, they were all sent in the name of the king, opening with the words 'de par le Roy', or in the name of his representatives in the city, the governor or the seneschal. ${ }^{33}$ Not only did this language help to identify the authority, it also informed the reader to treat the pamphlets with an appropriate level of attention and solemnity. The coat

31 Baudrier, Bibliographie lyonnaise II, pp. 112-118.

32 AML, CC 1194; CC 1199; CC 1210; CC 1223; CC 1230; CC 1233; CC 1237; CC 1243; CC 1247; CC 1249; CC 1257; CC 1268; CC 1272; CC 1276; CC 1281; CC 1283; CC 1286; CC 1291. AML, 6 FI 651. 


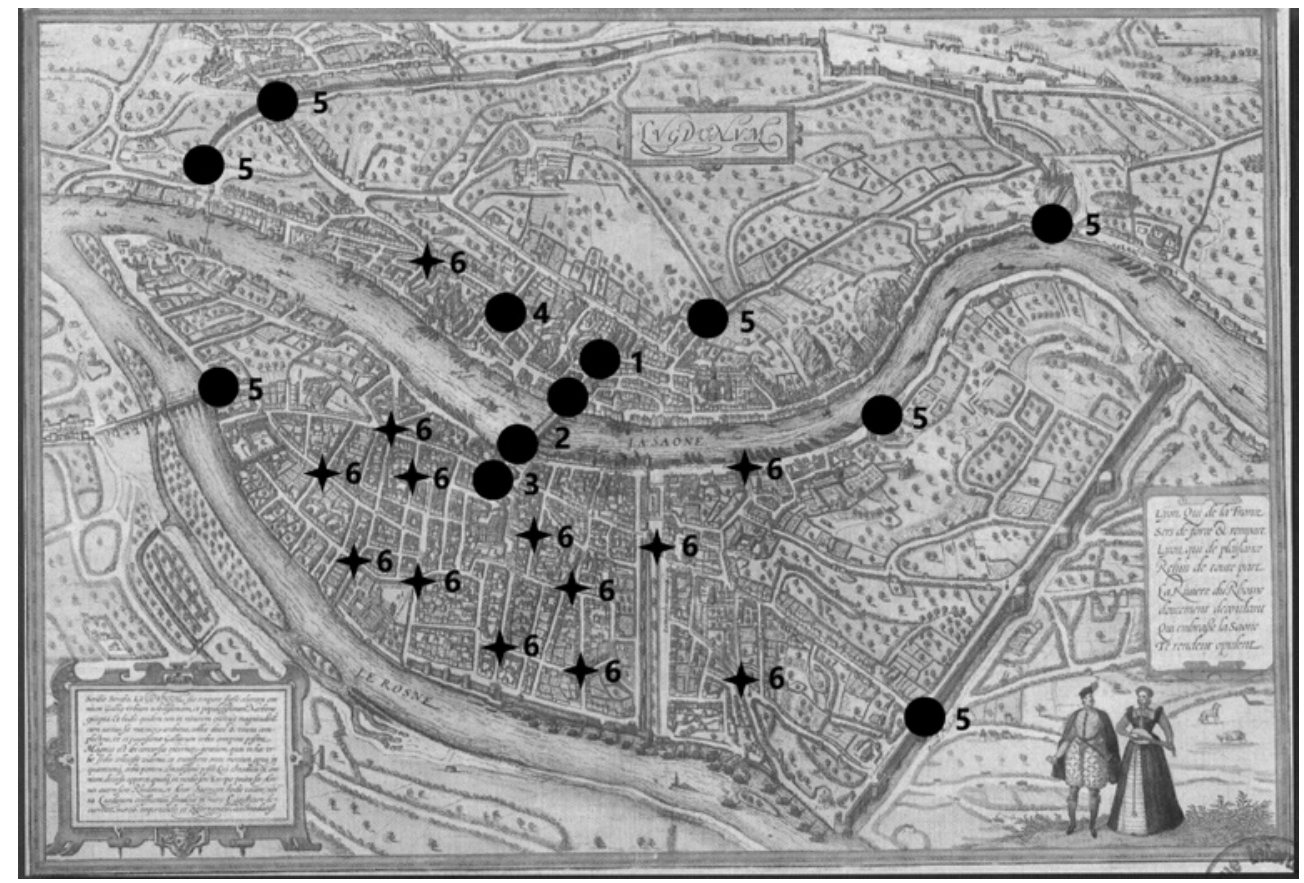

FIGURE 2.2 Strategic locations where print was displayed in 1568. 1: Place des Changes; 2: Pont de Saône; 3: Place de l'Herberie; 4: Palais de Roanne; 5: City gates; 6: Crossroads and other places

of arms, as a traditional symbol of power, worked alongside this official language by marking print with an official seal. ${ }^{34}$ These tokens of power were a way to highlight the legitimacy and the authoritativeness of the message sent.

Once the broadsheet was published, its manner of circulation was meant to be as official as possible. The posters and the broadsheets were displayed or distributed in very specific locations throughout the city, usually controlled by the authorities. The order that dates back to January 1568 offers more detail about the settings chosen, namely the Place des Changes, the Pont de Saône, the Place de l'Herberie, the city's crossroads and the gates..$^{35}$

Each location had its own strategic importance within the urban fabric. The two Places played a central role for trade and were, unsurprisingly, often frequented by the city's inhabitants. Crucially, the Pont de Saône constituted the only passage between the two shores of the river and was a key crossing point

34 Bruno Dumézil and Laurent Vissière (eds.), Épistolaire politique II. Authentiques et autographes (Paris: Presses Universitaires de Paris Sorbonne, 2016), pp. 8-9.

35 Ordonnance de messieurs les Seneschal et gens tenans le siege presidial en la ville de Lyon (Lyon: Michel Jove, 1568), ustc 5333. 
in the city. As for the gates of the governor's palaces or of the city hall, these stood out as symbols of authority and power. ${ }^{36}$ The gates of the city constituted a threshold which, once crossed, implied that all onlookers entered the jurisdiction of the municipality and were aware of the information displayed in print. Displaying placards at the gates of the city meant that the authorities aimed to notify all foreigners entering the city of their decisions. By displaying information to all newcomers, the council made it impossible for anyone to contest them on the grounds that they were not informed. Through this process of exploiting urban spaces, print became a token of authority. ${ }^{37}$ Placing placards at the very entrance of the city symbolically reaffirmed their importance over all other written documents.

Displaying printed documents in these locations meant that new actors intervened in the process of spreading official information. Even though the town crier usually had a role to play, and was expected to help affix posters, the municipality sometimes relied on different personnel who were supposed to receive and put up the posters, acting as representatives of the city council: the pennons and the dizeniers. ${ }^{38}$ This large group of employees were citizens who carried weapons and formed an urban militia in the service of the consulat so as to uphold order in the city. ${ }^{39}$ For example, in ${ }_{1575}$, these municipal employees were expected to handle the official broadsheets and, more importantly, to enforce the decisions printed by the city council in their constituencies. The pennons and the dizeniers did not publicly cry messages, nor did they have any instruments or wear specific uniforms. However, these messages were still understood as an authoritative communication from the échevins. In this specific case, this evolution of personnel suggests the growing importance of print in decision-making. When the city government used these municipal employees, they were using print alone without resorting to orality. Printed messages were indeed sufficient to symbolise authority and no longer needed to be surrounded by a proclamation ceremony to legitimise the message conveyed. Print became ceremonial in itself and was enough to affirm the authority of its authors. It could then become a full-fledged tool for government practices.

36 The city hall does not appear on the map because its exact location is not known for the 1560s. It is very likely to have been in the neighborhood of the Saint-Nizier church, between the Rhône and the Saône rivers, but it was not an official building. However, the palace of the governor is located near Saint-Jean, in the palace of Roanne.

38 AML, CC 1241.

39 Robert Descimon, 'Milice bourgeoise et identité citadine à Paris au temps de la Ligue', Annales E. S. C., 4 (1993), pp. 885-9o6; Serge Brunet and José Javier Ruiz Ibáñez, Les milices dans la première modernité (Rennes: Presses Universitaires de Rennes, 2015). 


\section{Print and Its Use to Control the City in Times of Civil War}

The use of print during the Wars of Religion provided a catalyst for such an evolution. As the city faced religious strife, the Catholic authorities did not hesitate to use print to harm their Protestant enemies. A broadsheet from 31 January 1568 provides a telling example. This broadsheet was published in the midst of the second civil war, during which the city of Lyon was not directly under attack, but local government still implemented a new set of rules to supervise the city and its population. Its text informed the Lyonnais people that all the belongings of the Huguenots, considered as rebels against the Crown, would be confiscated on command of the king. ${ }^{40}$ The broadsheet also listed the names and statuses of hundreds of Protestants from Lyon. The order was spread in multiple ways: it was cried and displayed throughout the city and was distributed as a booklet. By disclosing the names and spreading them in a booklet, the intention was clearly to turn the Huguenots into easily identifiable enemies. These documents were supposed to fuel denunciations and encourage the public to purge the city of the heretics. Print was used as a weapon that aimed to display the unwavering Catholicism of the authorities and their willingness to unify the community against the threat of heresy. Such a use of print was unique in Lyon, and does not seem to have occurred again during the Wars of Religion in France. ${ }^{41}$ It is a concrete example of how print was brought into play by Catholic authorities against the perceived Protestant threat.

Print also became a tool to control the Catholic population. To make information circulate more efficiently, small notes were distributed directly to the citizens in Lyon to notify them about the decisions made by the échevins. An example of such a practice can be found in 1575 . On 16 September, the consulat received the news that German troops were passing through the vicinity of Lyon to join Henri de Montmorency-Damville and his allies, known as the 'malcontents' 42 The city council took this news very seriously, not only because of its content but also due to its origin. The information was immediately believed to be true because Henri III had written to the governor. In these dangerous circumstances, the consulat immediately requested that Michel Jove print notes and posters, which would be distributed and put up at the gates

$40 \quad$ Ordonnance de messieurs les Seneschal et gens tenans le siege presidial en la ville de Lyon (Lyon: Michel Jove, 1568), UsTC 5333.

41 Even during the years of the Ligue, no such document was reprinted, see Estier, '15891594: la maîtrise de l'opinion à Lyon pendant la Ligue', pp. 4-6.

42 AML, B B 93. The malcontents is the name given to the Catholic and Protestant lords who formed a coalition to oppose the Crown after the Saint-Bartholomew's massacre in 1572. 


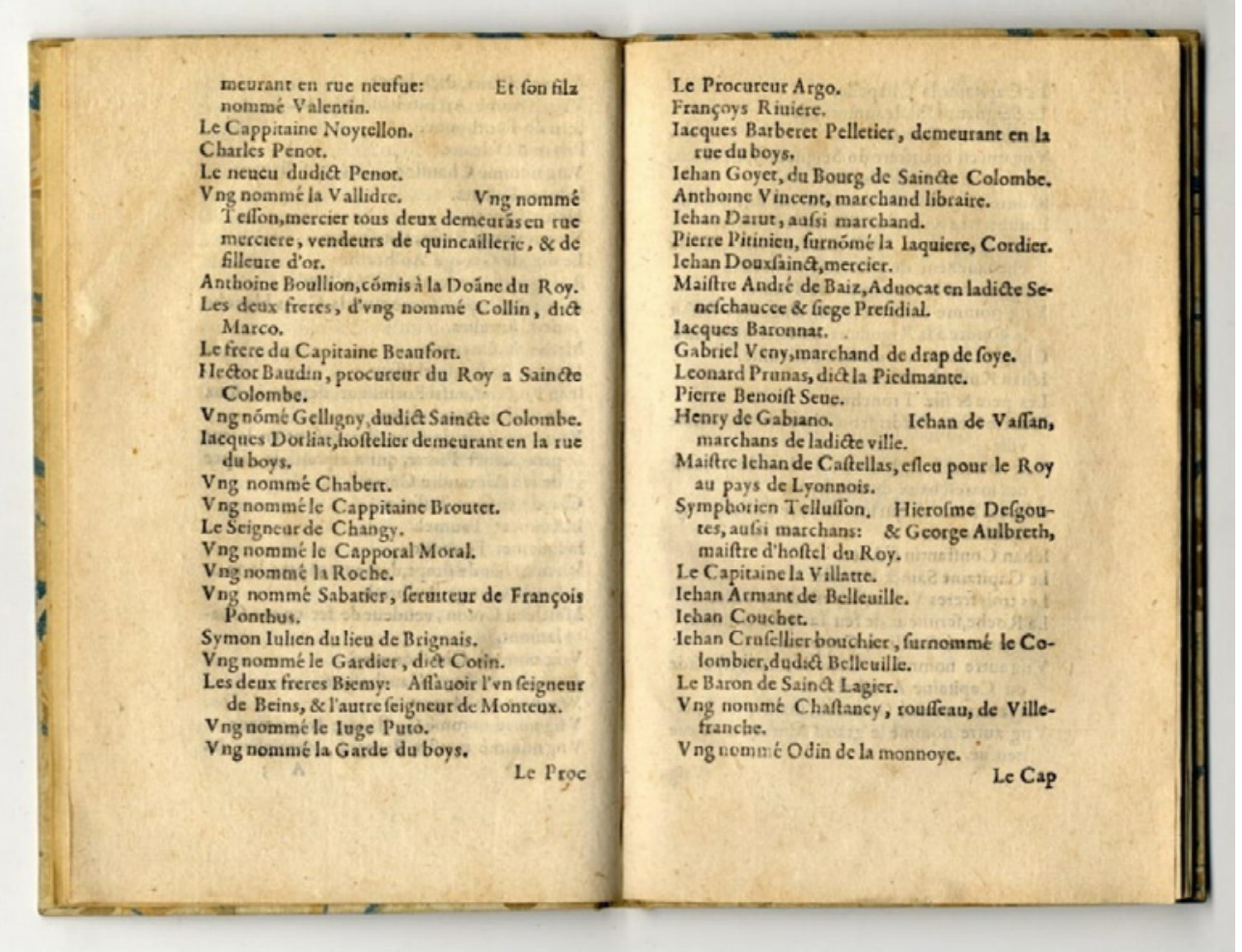

FIGURE 2.3 Ordonnance de Messieurs les Seneschal \& gens tenans le siege Presidial en la ville de Lyon MUSÉE DE L'IMPRIMERIE ET DE LA COMMUNICATION GRAPHIQUE DE LYON.

ALL RIGHTS RESERVED

of the city. The exact content of these notes is not known, but, according to the commission in the city's registers, the posters demanded that the vagrants leave the city, and that foreigners give their identity to the consulat. It also prohibited innkeepers from hosting unknown people. These notes were distributed daily from 16 September 1575 to 3 April 1576 at every gate of the city under the watch of the pennons and the dizeniers. ${ }^{43}$ In these dramatic circumstances, the traditional channels of information were completely transformed.

Interestingly enough, the city used only print in this case, as it enabled a broader distribution of the official message in a context of war and urgent threat. Print proved more efficient because of how it also allowed the authorities to reach the addressees in a physical sense, as the notes were handed over in person. These notes are an interesting case study of speech acts, which 
means that they did not merely present information, but also performed an action through language. ${ }^{44}$ In this case, the action performed by print is to make the decisions of the urban powers immediately effective, without resorting to public criers. Indeed, the authority of the printed document alone was supposed to guarantee that those receiving it would respect the order. Notes were also meant to encourage the circulation of information, as the person receiving them was implicitly trusted with the mission to pass them along to his acquaintances. Resorting to print was consequently more efficient than orality, insofar as the written word can make the information it communicates more memorable. It succeeds in anchoring the information in a specific time and place, making it more permanent and therefore more graspable. Print was the medium that enabled the authorities to maintain information over time, thanks to the duplication of documents. Last but not least, print allowed the authorities to spread information quickly, durably over the course of several months and at less cost, compared to handwritten documents.

Despite their use of print in times of war, the city council still employed it only occasionally. More often than not, the orders given in service of city administration had to be immediately effective, and their lifespan was necessarily very short because they were quickly replaced by new instructions. Interestingly, the use of print turned out to be less efficient than orality and public crying in the resolution of day-to-day affairs that require rapidity. The situation differed when the city had to face lasting predicaments, as in times of plague.

\section{Print and Its Use to Regulate an Urban Health Crisis}

The fight against epidemics and the mission to guarantee the good health of the Lyonnais inhabitants fell to the city council and the governor of the city. As early as the end of the fifteenth century, city authorities used print to warn the community about the dangers of disease. Throughout the sixteenth century, the city of Lyon was hit by plague; some outbreaks of the disease were more aggressive than others. ${ }^{45}$ From 1577 onwards, after a major outbreak of plague in Northern Italy, the échevins ordered that documents related to health issues

44 John L. Austin, Quand dire c'est faire (Paris: Seuil, 1970).

45 During the period under study, Lyon was affected in 1564, 1577, 1579, 1580, 1582, 1586 and $1587-1588$. However, all these outbreaks are not only due to the plague, as the urban powers use this term to name many epidemics without necessarily making a clear distinction between all the diseases present in the cities. Thus, the 1580 outbreak might actually be a case of pertussis rather than the plague. Rubys, Histoire véritable, p. 429. 
were to be printed and put up, following a method that had been used in previous decades. Several of these documents have been conserved in the city's archives. In this case, the city council expanded its use of print with the use of bullettes. These printed documents were certificates, emanating from the local authorities, whose purpose was to ensure the good health of the bearer of the document. These documents were handwritten in the 155 os and the 156 os, but started to be printed at the end of the 1570s. ${ }^{46}$ The Lyon Archives Municipales do not have exemplars of bullettes issued by the city of Lyon, but they have preserved several ones from Marseille, for which the bearers were Marseillais people travelling to Lyon. ${ }^{47}$

The bullettes were forms that were distributed in the city. The names and signatures of the échevins were added to these printed forms by hand, which associated them with the municipal power that had issued them. Print does not seem to have been able to symbolise the authorities' power by itself, hence the need for handwritten signatures. ${ }^{48}$ The coexistence of print and manuscript on the bullettes proves that the latter was still necessary to make these documents fully official. Indeed, unlike decrees, bullettes were distributed outside the city and their intended recipients needed to be convinced of the truthfulness of the documents. Such a degree of precaution was not necessary when the urban elite conveyed information in their own city through decrees. By contrast, these bullettes were printed in Marseille in order to be used in Lyon. They likely used handwriting in addition to print for bullettes, because it was a more traditional and generally accepted way to transmit official information. A signed document might have been more likely to be believed to be true and valid. This hybrid form also suggests that the use of print was still experimental and was undertaken with hesitation when it was intended for external authorities.

Similar documents were used by the city of Lyon and distributed in the region. In 1586, as the plague threatened Lyon, the échevins travelled to neighbouring villages for ten days to inform them about the measures taken in the city to avoid the plague. Their message was oral, but a poster was also put up at the gate of the villages' churches, and bullettes were printed and given to the local authorities so that they could distribute them to parties visiting Lyon. Some of the bullettes circulating were even meant to be given to other

\footnotetext{
46 АМL, Вв 84.

47 AML, AA 73.

48 Béatrice Fraenkel, 'La signature: du signe à l'acte', Sociétés et représentations, 25:1 (2008), pp. $19-26$.
} 
neighbouring villages that were not visited by the échevins. ${ }^{49}$ In this specific case, print became a governmental tool that exceeded the limits of the city. Whether transmitted by a town crier or not, print grew into an authoritative medium, diffusing reliable information even outside the city. More importantly, it allowed authorities to spread the decisions they made to a much wider audience. Its format also individualised the information, as it indicated the identity of the bearer of the bullette. It also helped the message to transcend time and space as it did not have an expiry date. In this case, decision-making was narrowly linked to the medium for the circulation of information. By choosing print, the échevins wished to make the information not only immediate, at the very first reading, but also able to endure for several years and to be valid throughout the different cycles of plague. Print was used far more than was common when it came to solving a health crisis because it enabled an administrative management of diseases and played a role in the prevention of the spread of plague.

However, the efficiency of such government practices cannot be fully verified. The municipal registers are silent about the concrete results of these printing campaigns, which makes it impossible to know whether the population was more receptive when the orders were printed rather than proclaimed. ${ }^{50}$ Nevertheless, the repeated remonstrance of the échevins and the governors against the gates' guards, who deserted their posts for several months in a row, sheds some light on this question. The guard's desertion obviously meant slowing down or even preventing the distribution of official forms, and therefore the circulation of official decisions in the city. ${ }^{51}$ These reiterated threats against the guards suggest that the proper reception of written orders by the Lyonnais people was not necessarily efficient because of the deficiencies of the personnel in charge of their distribution. However, the more consistent and diversified use of print seems to signal a change in the perception of this medium, which the urban elites had begun to integrate into their government practices.

\section{Conclusion}

Decision-makers increasingly relied on print because of the efficient diffusion of information it enabled. However, at the end of the sixteenth century, these

\footnotetext{
49 AML, 3 GG 4.

$5^{\circ}$ About the contestation of public cries see: Nadrigny, Information et opinion publique, p. 26 o.

51 AML, BB 94, BB 98.
} 
new communication strategies represent only the early stages of this relation between print and decision-making, as print was not used systematically. The urban powers' choice to print official documents was not standardised and was far from being perfectly efficient, but proves that authorities were, however gradually, willing to make use of print technologies. The goal of the authorities was to introduce new forms of information media in order to optimise their strategy for communicating with the urban community. Print was used as a new source of information, which redefined traditional channels of official communication, intertwining written and oral messages. Therefore, print managed to coexist with orality and, though to a somewhat limited extent, became one of the information media of Lyon's urban elites.

The bullettes present a stronger case for the expedience of print than the devastating Wars of Religion. The various examples of printed documents studied prove that print was used very differently depending on political and social circumstances. In times of war, print was not expected to solve any crisis. Instead, the city government deployed print to spread short-term information as a way to control the population and to re-establish order inside the city. Given how temporary war information was, the échevins favoured public crying because of how quickly it allowed any message or piece of information to be replaced by a new one. When it came to containing plague, print implied a very different relation to time and decision-making. The city government favored printed documents because of the cyclical nature of epidemics, which were likely to last for a long period of time. Bullettes were indeed reusable from one health crisis to the other. Similarly, throughout a plague outbreak, print allowed urban powers to deliver messages that remained valid and legitimate in the eyes of the population.

Print was only one of the many tools of government employed by the city council and the governor. Only several decades later would the use of print become standard in the political practices of French urban elites. This medium would eventually become the way of transmitting the most authoritative and trusted documents circulating in the city, and would then impose itself in the exercise of power as a form of speech act on which the local authorities would rely. 